\title{
Shell morphology, growth and longevity of Unio tumidus (Bivalvia: Unionidae) from an archaeological site and contemporary population inhabiting the Oder estuary
}

\author{
Przemysław Czerniejewski (D) Jarosław Dąbrowski - Wawrzyniec Wawrzyniak • \\ Adam Brysiewicz $\mathbb{D} \cdot$ Orina Surma
}

Received: 20 July 2020/Revised: 29 April 2021 / Accepted: 2 May 2021 / Published online: 22 May 2021

(C) The Author(s) 2021

\begin{abstract}
Mussel shells are often found in archaeological excavations and can provide information useful for ecological reconstruction and assessment of anthropogenic impact on waters. In this study, two sample groups of swollen river mussel (Unio tumidus) which occurred during the Early Middle Ages (EMS) and currently (MS) in the Oder river estuary (Baltic basin) were compared. Allometric shell growth, morphological characteristics of the shell (length, width, height and thickness), age structure and growth of mussels were analysed using the von Bertalanffy equation. All three types of allometric growth (isometry and both positive and negative allometry) were observed in the studied mussels. In both groups, typical values of shell length, width, height and thickness were recorded. However, higher values of
\end{abstract}

Handling editor: Manuel Lopes-Lima

P. Czerniejewski · W. Wawrzyniak

Department of Commodity, Quality Assessment, Process Engineering and Human Nutrition, West Pomeranian University of Technology in Szczecin, Szczecin, Poland

J. Dąbrowski · A. Brysiewicz ( $\square)$

Institute of Technology and Life Sciences - National

Research Institute, Hrabska 3 Ave.,

05-090 Raszyn, Falenty, Poland

e-mail: a.brysiewicz@itp.edu.pl

\section{O. Surma}

Faculty of Health Sciences, State University of Applied

Sciences in Konin, Konin, Poland these morphological characteristics were recorded in the EMS group. Moreover, the EMS group, compared with the MS group of $U$.tumidus, was characterised by a higher longevity (12 and 10 years, respectively) and asymmetric length $\left(L_{\infty}\right)(93.09$ and $83.23 \mathrm{~mm}$, respectively). Both groups of mussels had a similar growth rate $(k)$. Larger shell sizes in the EMS group were probably caused by differential preservation and/ or differential archaeological recovery, and resulted from differences in the age structure, especially higher mortality rate amongst individuals older than 6 years in the MS group.

Keywords Structure $\cdot$ Molluscs - Increase $\cdot$ Age . FSA

\section{Introduction}

Freshwater mussels are widely distributed throughout the world and are present in all continents except Antarctica (Graf \& Cummings, 2006), but they are also severely endangered worldwide (Lopes-Lima et al., 2017; Böhm et al., 2020; Graf \& Cummings, 2021). Their oldest representatives existed as early as during the Triassic period (Watters, 2001). Due to their filtration capacity, they play a significant role in the functioning of aquatic ecosystems, affecting the physical and chemical conditions, as well as the 
structure and habitats of other organisms (Ziertitz et al., 2019). For example, Aldridge et al. (2007) observed a positive correlation between high densities of freshwater mussels and the diversity of other invertebrate taxa. On the other hand, a study by Vaughn \& Hakenkamp (2001) showed that at high densities, mussels are able to significantly reduce phytoplankton biomass and reduce phosphorus content, leading to a better water transparency. Mussels as animals with a high ecological specialisation are good environmental bioindicators (Grabarkiewicz \& Davis, 2008; Ganzei et al., 2020). Amongst the most remarkable freshwater bivalves are species belonging to the order of Unionida, which represents about $72 \%$ freshwater mussels (Lopes-Lima et al., 2018). The most numerous family of this order is Unionidae, which comprises 753 species in 153 genera (Graf \& Cummings, 2021). In archaeological studies, they are a group of marker organisms used in "applied zooarchaeology" (Peacock et al., 2016) for the reconstruction of past climatic conditions, as well as the palaeoenvironment and its changes, including those of anthropogenic origin (Mitchell \& Peacock, 2014; Mitchell, 2017; Peacock et al., 2017). Moreover, they widen our knowledge of the population composition and natural distribution (biogeography), biodiversity in various water types before changes related to human activity (Mitchell et al., 2016). The results of those studies also give some insight into the rate and direction of changes in the mussel population, allowing protection of the endangered species (Peacock et al., 2017). For the majority of known species we are currently aware of the environmental requirements; therefore, if we admit that both now and in the past the species have similar environmental requirements (Lyman, 2017), the presence or absence of a taxon in the environment is a proof of habitat modifications. Moreover, learning about biological diversity from distant past with the use of currently available novel laboratory techniques enables accurate and thorough identification of species translocation mechanisms (DiNapoli et al., 2021).

Unionids produce hard parts, which are found, despite taphonomic and diagenetic processes in sedimentary deposits and as such can be used in the reconstruction of ancient populations and species. These processes cause mechanical and chemical degradation of the shell by dissolution and recrystallization, resulting in their fragmentation, although the shells are characterised by high resistance to crushing thanks to their structure (Barthelat et al., 2009), loss of colour, chemical dissolution and precipitation of calcite (Peacock et al., 2020). According to Wolverton et al. (2010) the factors influencing these processes include the discard process (e.g., height from which shells are dropped by people), orientation of deposition, disparity in burning amongst shellfish remains of different species, rate of disarticulation of valves, exposure to trampling, chemical weathering in acidic soils, soil formation processes, rates of deposition, sedimentation and erosion, archaeological recovery methods, modification of shells by predators, and shell shape and microstructure.

In Poland, remains of molluscs are found at archaeological sites much less frequently than those of vertebrates (Zabilska, 2012). In the case of molluscs, the most common remains found at archaeological sites in Poland are shells of mussels (Unionidae), in particular Unio tumidus Philipsson, 1788 (Dzięczkowski, 1998), which were used as food by the ancient residents (Kurzawska, 2015). The number of unionid shells found in the various archaeological layers indicates that they were also present in the waters surrounding the medieval Wolin, located in the Oder estuary, and used as additional food for the inhabitants (personal information from Prof. W. Filipowiak). Currently, a representative of the Unionidae family, U. tumidus, is an abundant species in the region (Wolnomiejski \& Witek, 2013).

The aim of this study was (i) to compare the population structures (length and age), and (ii) to compare the longitudinal growth and shape of the shells of $U$. tumidus, between a shell midden excavated in Wolin town (Oder estuary) and shells from a contemporary population inhabiting the Oder estuary, with the two groups separated by approximately 1000 years.

\section{Material and methods}

Study site

The study material were shells of the mussel Unio tumidus originating from an archeological excavation (78 shells, called the Early Middle Ages groupEMS) and those harvested during fishing with a bottom dredge ( 88 shells, group harvested in the 
twenty-first century-MS) in the northern part of the Szczecin Lagoon (Oder estuary). Material for the first group was collected from an archaeological excavation situated on the island of Wolin in the area of the old town of Wolin, approx. $60 \mathrm{~m}$ from the west bank of the Dziwna river (Oder estuary) (Fig. 1).

The excavation covered an area of $5 \mathrm{~m} \times 20 \mathrm{~m}$ and reached a face located at a depth of $7 \mathrm{~m}$. The studied shells were collected from layers corresponding to the following periods: tenth century, 1 st half of the eleventh century, 2nd half of the eleventh century (Chełkowski et al., 2001). Shells for the second group were collected from the 2nd to 16th of October 2019 during fishing for macrozoobenthos using a bottom dredge at sites located in the Dziwna river and in the northern part of the Szczecin Lagoon (Oder estuary) within $1000 \mathrm{~m}$ of the excavation site.

Morphology and species identification

Shell morphology (including length, width, height and thickness) is one of the important qualities for biologists, allowing for species identification of the

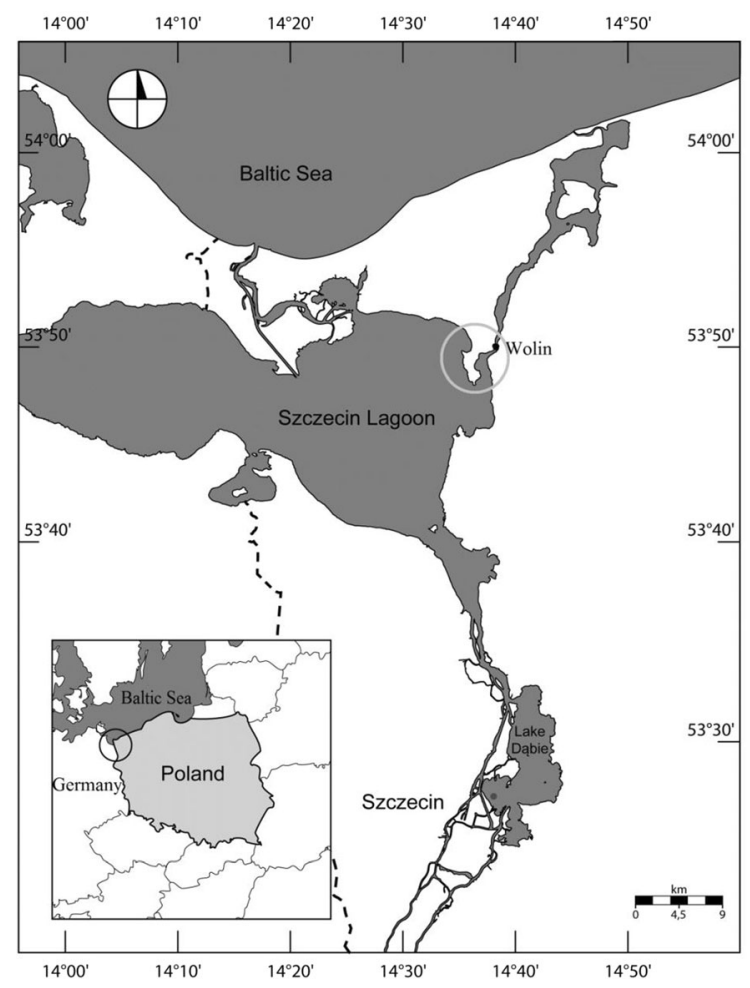

Fig. 1 Sampling site location mussel (Aldrige, 1999; Rizhinashvili, 2008; Bogan \& Roe, 2008). Of special importance are proportions between particular morphological features, which reflect the shape of the shell (Wolverton et al., 2010).

The collected shells were measured with an electronic calliper $(0.01 \mathrm{~mm}$ measurement accuracy) to record the following parameters: maximum height $(H)$, maximum width $(W)$, maximum length (L) (Fig. 2) (Aldridge, 1999; Wolverton et al., 2010) and the thickness of the valves (T) (Ożgo et al., 2012). The thickness of the valves was measured at the centre of gravity of each valve. Centre of gravity is the point of contact of the valve with the surface on which it is placed concave side up. Of the harvested shells, only whole ones (non-fractured, retaining their umbo) and only those belonging to Unio tumidus were studied, whilst other ones were rejected.

After a logarithmic transformation $(\log 10)$ of the morphological measurements, a linear regression analysis was conducted ( $W-L, H-L, T-L, W-H, T-$ $H$ ) using standard major axis regression (SMA) (Warton et al., 2012). The slope of the regression (allometric coefficient) was used as an indicator of the
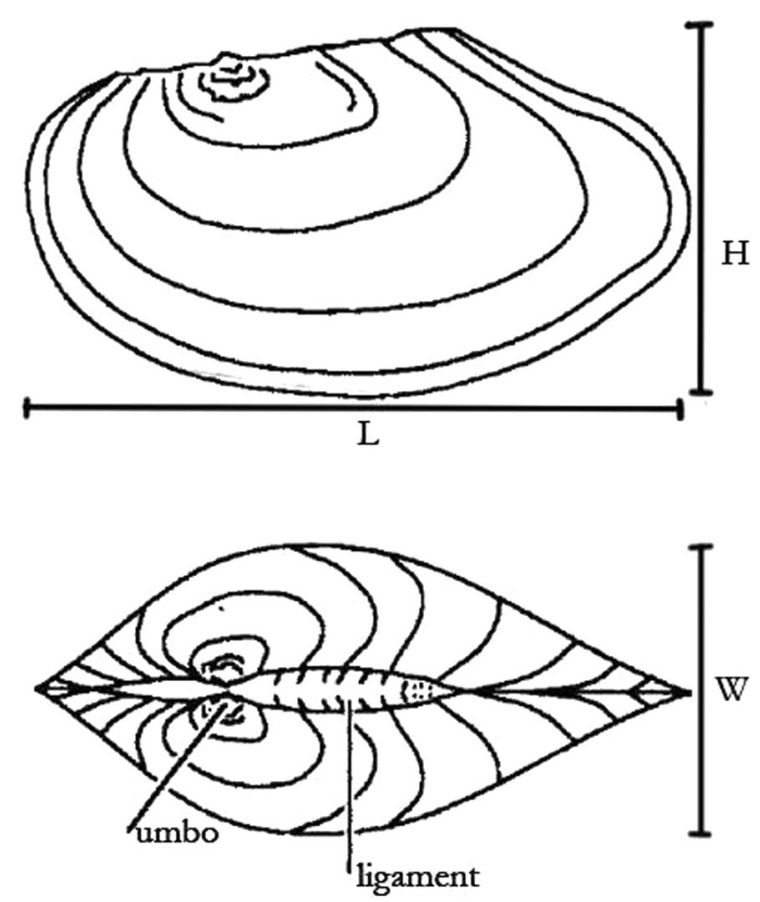

Fig. 2 Standard measurements of the shell. $H$-maximum height, $W$-maximum width, $L$-maximum length (Aldridge, 1999, as modified) 
type of differential growth, considering the 95\% confidence intervals, calculated for each coefficient.

Age and growth

Age was determined by counting the annual rings on the surface of mussel shells (Rizhinashvili, 2008; Johnsson et al., 2013), by 2 independent researchers. In order to confirm the compatibility of age and location of each annulus for 36 selected shells, a procedure described by Haag \& Comments-Carson was used (2008). The shells were cut with the use of the Buehler Isomet low speed saw (Buehler Ltd., Evans-ton, IL, U.S.A.), with a diamond blade. Vernier callipers ( $0.01 \mathrm{~mm}$ measurement accuracy) were used to measure the length of individuals at each annulus. The growth of shells was described using the von Bertalanffy equation (Haag \& Rypel, 2011):

$L_{t}=L_{\mathrm{inf}}\left(1-e^{-K\left(t-t_{0}\right)}\right)$

where $L_{t}$ is length (mm) at time $t$ (age in years), $L_{\text {inf }}$ is length $(\mathrm{mm})$ at time infinity (the predicted mean maximum length for the population), $K$ is a growth constant which describes the rate at which $L_{\text {inf }}$ is attained $\left(\mathrm{mm}\right.$, year $\left.{ }^{-1}\right), t$ is age (years) and $t_{\mathrm{o}}$ is the time at which length $=0$. The parameters of the above equation were calculated in the $\mathrm{R}$ programming environment with FSA packages, nlstools, magrittr, dplyr, nnnet (Ogle, 2016).

The obtained data were used to calculate the maximum age that Unio tumidus reached in the early Middle Ages and currently, using the equation (Ziuganov et al., 1994):

$t_{m}=-1 / K \ln \left[1-\left(L_{\mathrm{m}} / L_{\infty}\right)\right.$

where $t_{m}$ is the maximum age and $L_{m}$ is the maximum length.

Statistical analysis

The data were tested for normality and homogeneity of variances by the Kolmogorov-Smirnov test and Levene's test, respectively. If necessary, data were log-transformed to meet these assumptions. The significance level for all analyses was set at 0.05 . The Wilcoxon test (Cohen \& Cohen, 2008) was used to compare the values of the measured parameters, whilst Student's $t$-test (Shahbaba, 2012) was used to compare slope in the analysis of growth allometricity and isometry of the parameters measured. Stepwise discriminant analysis was used to identify the combination of variables that best separated the two groups (Bocard et al., 2018). Unless otherwise stated, statistical analyses were conducted with Statistica 13.0 (Statsoft Inc.), the $\mathrm{R}$ programming environment ( $\mathrm{R}$ Core Team, 2013) and the $\mathrm{R}$ package nlme (Pinheiro et al., 2020).

\section{Results}

Shell morphology

The shells of Unio tumidus from the Early Middle Ages (EMS group) were characterised by a significantly greater length $(L)$, width $(W)$, height $(H)$ and thickness $(T)$ compared with the contemporary individuals (MS group) (Table 1). Moreover, the distribution of these parameters showed clear differences in shell size between the two groups (Fig. 3). The discriminant analysis (Table 2) indicated that the thickness, maximum length and height of shells are statistically significant variables which allow discriminating between the two studied groups of mussels. Cross-validation with the split-sample method indicated a $95.88 \%$ overall success rate $(98.75 \%$ of the EMS group and $93.33 \%$ of the MS group were correctly assigned).

Regression equations for the shell morphology of the $U$. tumidus EMS and MS subgroups are given in Table 3. The equations demonstrate that all models were statistically significant (at $P<0.05$ ). Growth could mostly be considered as allometric (positive and negative), except $T-L, W-H, T-H$ for the MS group for which isometric growth was recorded. By comparing the slope parameters $(b)$ of each regression between the mussel groups (Table 4), it was shown that statistically significant differences were present only in those regressions in which thickness $(T)$ was the independent variable.

Age structure and growth

The comparative analysis between the methods of age determination (by counts of external annuli and by thin section) for 36 randomly selected mussels showed age compatibility for both methods in 31 individuals. Only 
Table 1 Morphometric data (mean $\pm \mathrm{SD}$ ) and the Wilcoxon test on Unio tumidus shells

\begin{tabular}{lllll}
\hline$U$. tumidus group & $L(\mathrm{~mm}) \pm \mathrm{SD}$ & $W(\mathrm{~mm}) \pm \mathrm{SD}$ & $H(\mathrm{~mm}) \pm \mathrm{SD}$ & $T(\mathrm{~mm}) \pm \mathrm{SD}$ \\
\hline EMS group & $64.77 \pm 9.20$ & $24.81 \pm 3.23$ & $31.81 \pm 4.08$ & $1.03 \pm 0.15$ \\
MS group & $59.47 \pm 6.78$ & $22.46 \pm 2.30$ & $28.90 \pm 2.86$ & $0.56 \pm 0.25$ \\
W statistic & 4720 & 4980 & 4874 & 6466 \\
$P$-value & 0.00003099 & 0.0000005519 & 0.000003095 & 0.000000000 \\
\hline
\end{tabular}
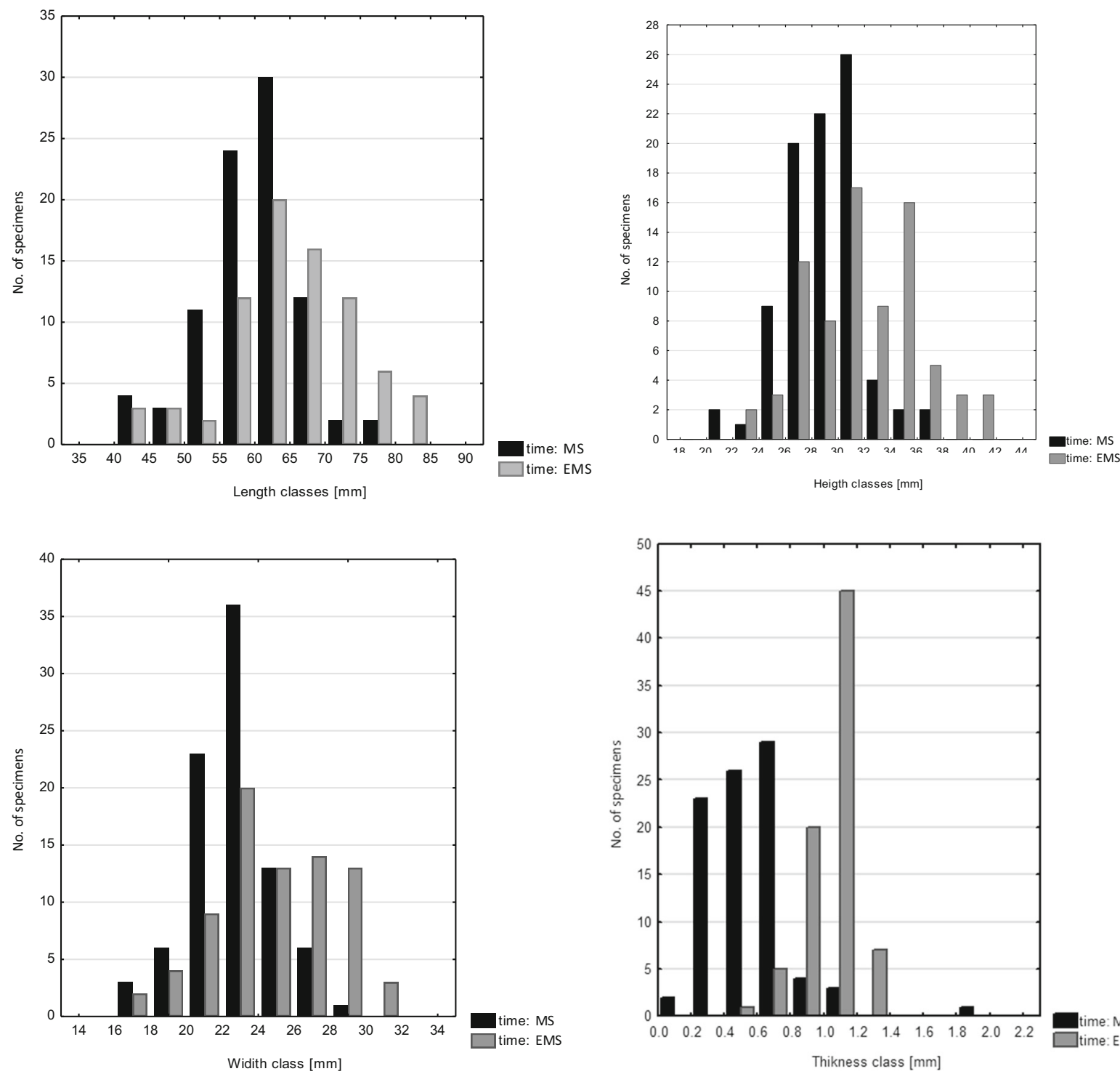

Fig. 3 Distribution of length $(L)$, height $(H)$, width $(W)$ and thickness $(T)$ of Unio tumidus shells from the Early Middle Ages (EMS) and present day (MS)

in 5 shells of mussels aged above 8 years, the mussel age was underestimated by 1 year using the method of counts of external annuli. Moreover, false annuli were occasionally recorded in the study shells. In the case of thin-sectioning, the method enabled identification of false annuli, since real annuli could be analysed from 
Table 2 Results of discriminant analysis of the morphological characteristics of mussel shells

\begin{tabular}{llcll}
\hline Variable & Wilk's Lambda & $F$-remove & $P$ & Tolerance \\
\hline$L$ & $\mathbf{0 . 3 7 8 2 0 8 *}^{*}$ & $\mathbf{3 0 . 0 2 2 7 *}^{*}$ & $\mathbf{0 . 0 0 0 0 0 0 *}$ & $\mathbf{0 . 0 6 3 7 1 5 *}^{*}$ \\
$H$ & $\mathbf{0 . 3 2 7 7 0 3 *}_{W}$ & $\mathbf{3 . 9 8 0 0}^{*}$ & $\mathbf{0 . 0 4 7 6 9 0}^{*}$ & $\mathbf{0 . 1 0 8 0 3 2}^{*}$ \\
$T$ & 0.323197 & 1.6564 & 0.199894 & 0.118409 \\
\hline
\end{tabular}

*Significant values are indicated in bold type

Table 3 Values of regression equations for Unio tumidus shell morphology and $P$-values of slope tests

\begin{tabular}{|c|c|c|c|c|c|c|c|c|c|c|}
\hline & Group & $n$ & Slope $(b)$ & Intercept $(a)$ & $r$ & $F$ & $P$ value & Growth type & $t$-value & $P$ value \\
\hline $\log W \sim \log L$ & EMS & 78 & 0.863 & -0.389 & 0.93 & 948 & 0.000 & A & 30.79 & $<0.00001$ \\
\hline $\log H \sim \log L$ & & 78 & 0.811 & 0.079 & 0.88 & 545 & 0.000 & A & 23.35 & $<0.00001$ \\
\hline $\log T \sim \log L$ & & 78 & 0.939 & -3.885 & 0.73 & 207 & 0.000 & I & 14.38 & $<0.00001$ \\
\hline $\log W \sim \log H$ & & 78 & 0.989 & -3.39 & 0.61 & 118 & 0.000 & I & 10.85 & $<0.00001$ \\
\hline $\log T \sim \log H$ & & 78 & 0.989 & -3.397 & 0.61 & 118 & 0.000 & I & 10.85 & $<0.00001$ \\
\hline $\log W \sim \log L$ & MS & 88 & 0.75 & 0.045 & 0.759 & 271.7 & 0.000 & A & 16.48 & $<0.00001$ \\
\hline $\log H \sim \log L$ & & 88 & 0.764 & 0.241 & 0.836 & 439.8 & 0.000 & A & 20.97 & $<0.00001$ \\
\hline $\log T \sim \log L$ & & 88 & 3.142 & -13.479 & 0.828 & 415.9 & 0.000 & A & 20.39 & $<0.00001$ \\
\hline $\log W \sim \log H$ & & 88 & 0.846 & 0.256 & 0.678 & 181.1 & 0.000 & A & 13.46 & $<0.00001$ \\
\hline $\log T \sim \log H$ & & 88 & 3.549 & -12.582 & 0.738 & 242.5 & 0.000 & A & 15.57 & $<0.00001$ \\
\hline
\end{tabular}

$A$ allometric growth, $I$ isometric growth

Table 4 Comparison of correlation factors and regression of slope between the groups of mussels from early Middle Ages and present day

*Significant differences are indicated in bold type

\begin{tabular}{|c|c|c|c|c|c|c|}
\hline & \multicolumn{3}{|l|}{ Slope $(b)$} & \multicolumn{3}{|l|}{$r$} \\
\hline & $t$-value & DF & $p$-value & $t$-value & $\mathrm{DF}$ & $p$-value \\
\hline $\log W \sim \log L$ & 1.829 & 162 & 0.069 & 3.981 & 162 & $0.000103 *$ \\
\hline $\log H \sim \log L$ & 0.909 & 162 & 0.364 & 0.968 & 162 & 0.334 \\
\hline $\log T \sim \log L$ & -13.087 & 162 & $<0.000001 *$ & -1.620 & 162 & 0.106 \\
\hline $\log W \sim \log H$ & 1.352 & 162 & 0.178 & 2.650 & 162 & $0.008839 *$ \\
\hline $\log T \sim \log H$ & 2.556 & 162 & $0.0115 *$ & -1.5577 & 162 & 0.121 \\
\hline
\end{tabular}

the umbo to the shell margin. False annuli were characterised by an incomplete growth line in thin sections.

In the age structure of mussels, individuals aged 5 and 6 years prevailed in both groups (Fig. 4). Fiveyear-old individuals constituted $21.56 \%$, and 6-yearold individuals constituted $33.33 \%$ of the EMS group. The corresponding values in the MS group were $34.09 \%$ and $40.91 \%$, respectively. In the MS group, the proportion of older age groups ( $>6$ years) was only $12.50 \%$, whilst in the EMS group, it was as high as $33.33 \%$, which means that mussel mortality rate in these age groups was higher in the contemporary individuals.

In individual age groups, the Early Middle Ages (EMS) mussels were characterized by greater length $(L)$, width $(W)$, height $(H)$ and thickness $(T)$ compared to modern mussels (MS) (Fig. 5a-d).

Figure 6 shows the growth of mussels from the EMS and MS groups based on the von Bertalanffy equation. The positions of growth curves and the equation parameters (Table 5) show that mussels in the 
Fig. 4 Age structure of mussels

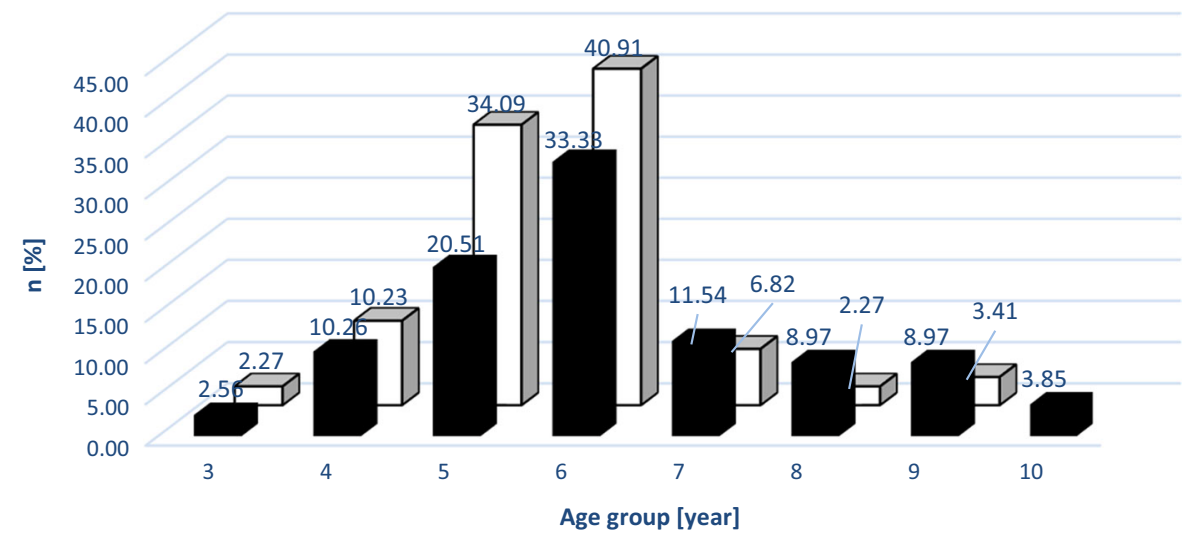

口[\%] Early Medieval Sample $\quad \square[\%]$ Modern Sample (a)

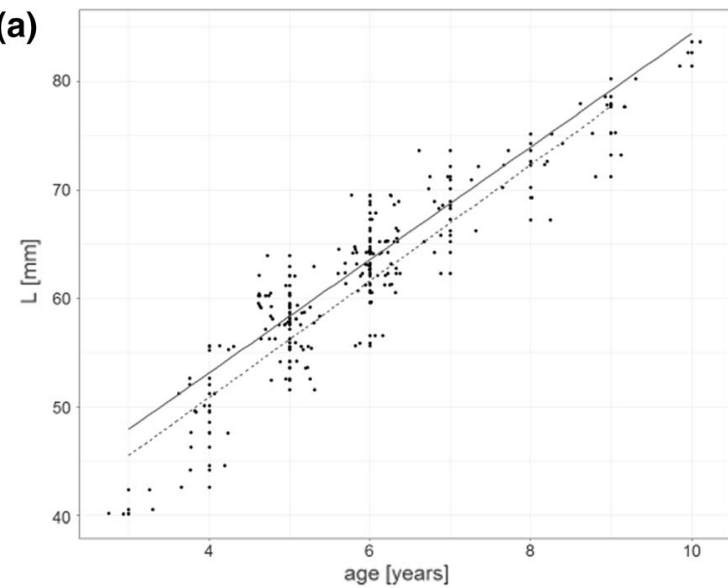

(c)

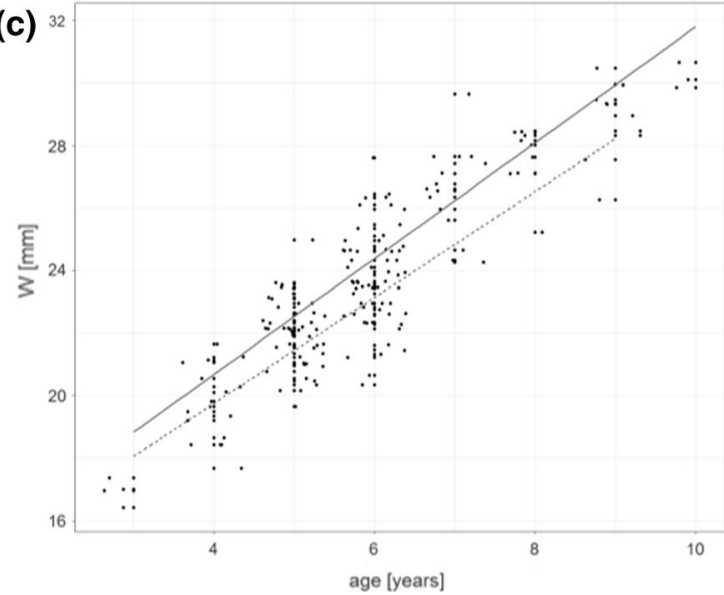

(b)
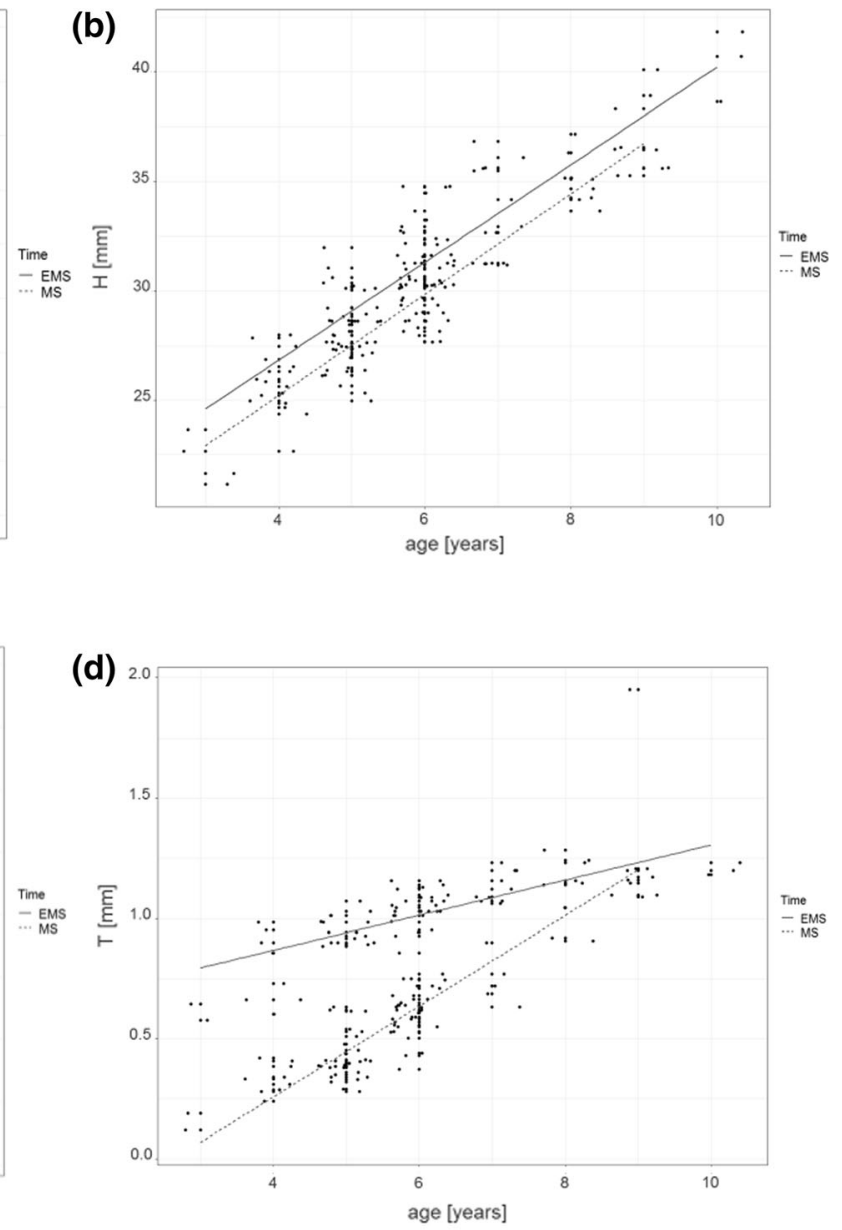

Fig. 5 Linear regression for Unio tumidus shell morphology. Regression between age [years] and length (a), height (b), width (c) and thickness (d) in time group 

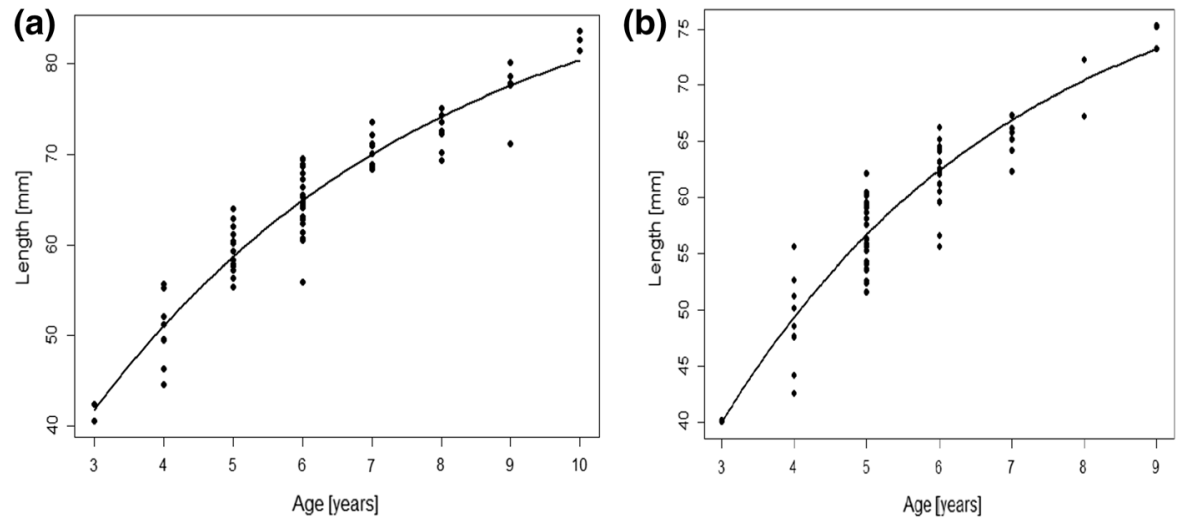

Fig. 6 Comparison of the growth rates of mussels from the early Middle Ages (a) and present day (b)

Table 5 Growth parameters for the investigated Unio tumidus populations from the Oder estuary

\begin{tabular}{llllll}
\hline Group & Growth constant $(k)$ & Asymptotic length $\left(L_{\infty}\right), \mathrm{mm}$ & $t_{0}$ & Maximum length $\left(L_{\mathrm{m}}\right)$, mm & Maximum age $(\text { years })^{*}$ \\
\hline EMS & 0.199 & 93.09 & 0.017 & 83.65 & 12 \\
MS & 0.243 & 83.23 & 0.309 & 75.32 & 10 \\
\hline
\end{tabular}

*Maximum age was calculated using the formula published by Ziuganov et al., (1994)

EMS group were characterized by higher longevity (maximum age for the EMS and MS groups was 12 and 10 years, respectively) and slightly higher asymptotic length $\left(L_{\infty}\right)(P=0.0365)$ compared with the currently occurring $U$. tumidus. Moreover, both groups showed similar growth rates, as indicated by parameter $k(P=0.0523)$.

\section{Discussion}

\section{Morphology}

The unionid fauna of the Szczecin Lagoon includes all the species belonging to the genera Unio and $A n$ odonta known to occur in Poland (Wolnomiejski \& Witek, 2013). As in other waterbodies in this part of Europe, commonly observed species include Unio pictorum (Linnaeus, 1758), Unio tumidus and Anodonta anatine (Linnaeus, 1758), whilst those observed much less frequently include Pseudanodonta complanata (Rossmässler, 1835) and Anodonta cygnea (Linnaeus, 1758) (Masłowski, 1993). This is probably due to the habitat preferences of these species which is mainly found on the silt or sandy bottom, rich in allochtonic organic matter (Abraszewska-Kowalczyk, 2002). The size of the U. tumidus shells from both the EMS and MS groups did not differ from the literature data. According to Piechocki \& Wawrzyniak-Wydrowska (2016), the length of the $U$. tumidus shell in Poland ranges from 60 to $100 \mathrm{~mm}$ (max $130 \mathrm{~mm}$ ), height 35-48 mm, width $25-37 \mathrm{~mm}$. On the other hand, in the lake complex Crapina-Jijila in the Danube delta, bivalves were 48-68 mm long (Tudorancea, 1972). However, what is interesting is the statistically significant difference between the morphometric parameters of the mussel groups in our study. Individuals originating from the eleventh century had a greater shell length, width and height, and nearly twice the thickness. This may result from differential preservation, differential archaeological recovery, or both. For example, denser and thicker mussel shells preserve better than the thinner ones, because the latter are more susceptible to damage (Wolverton et al., 2010). Nevertheless, it seems that differential preservation affects mainly small and thin shells of young individuals. Aside to taphonomic changes, the mussel structure could have also been affected by "cultural filter" constituting selective human activity (human preferences or avoiding 
certain species) (Mitchell, 2017). A decrease in the average shell length of this species, although over a relatively shorter period compared with our study (approx. 50 years), was also observed in the $U$. tumidus population in Lake Mikołajskie (Lewandowski \& Kołodziejczyk, 2014). However, Peacock (2000) and Miller et al. (2014) reported usually larger dimensions in present-day mussels compared with the same species from Holocene archaeological excavations. These long-term disparities are likely to result from changes in the environmental conditions over many years due to progressive eutrophication, currently accelerated by human activity (Peacock \& Mistak, 2008; Fritts et al., 2017) and temperature changes (Lundquist et al., 2019). As emphasised by numerous authors, climate changes over nearly 1000 years may also affect the age, growth and size of mussel shells (Holland et al., 2014; Lundquist et al., 2019). Especially because the first study group of mussels (EMS) probably lived in an optimal medieval climatic period, and the temperature differences between these periods were sufficiently high to have caused disproportions in their shell sizes (Schöne \& Fiebig, 2009). This effect is more pronounced in freshwater, rather than marine species, since temperatures of fresh water are largely dependent on the air temperature, and habitats are often fragmentary, which limits the free movement of species with progressive environmental changes (Woodward et al., 2010). Moreover, it is common knowledge that freshwater mussels grow more slowly and reach more advanced age in the higher latitudes (Haag \& Rypel 2011), where the air temperature is lower (Hu et al., 2018). Higher water temperature accelerates the photosynthesis of phytoplankton, one of the basic nutrient of mussels, which has a logarithmic effect on their growth rate. However, very large concentrations of food particles cause reduction in the filtration rates. Filtration rates of Dreissena mussel fed with Nitzschia diatoms were observed to increase up to $2 \mathrm{mg} \mathrm{C} / \mathrm{L}$ with about $40 \%$ of assimilation performance. Plateau occurred above the level of $2 \mathrm{mg} \mathrm{C/L}$ (Wetzel, 2001). Mussel growth is affected not only by longevity, as claimed by Haag \& Rypel (2011), or food amount (Wetzel, 2001), but also by the concentration of calcium and bicarbonates in water. Carey et al. (2013) indicate that a temperature increase causes an increase in the rate of growth of young Epioblasma brevidens (I. Lea, 1831) and E. capsaeformis (I. Lea, 1834), as well as a decrease in the rate of growth. A different opinion was presented by Ganser et al. (2015) who showed that an increase in the temperature of water where Unionidae [Amblema plicata (Say, 1817), Elliptio complanata (Lightfoot, 1786), Fusconaia flava (Rafinesque, 1820) and Lampsilis cardium Rafinesque, 1820] mussels lived caused a change in the rate of metabolism, such that it might lead to a decrease in the energy necessary to survive, grow and reproduce.

Age and growth of mussels

In mussels, growth and longevity depend on species, sex and habitat conditions (Aldridge, 1999; Lundquist et al., 2019). Haag \& Rypel (2011) observed that values of the growth constant $K$ ranged from 0.05 [Quadrula asperata (I. Lea, 1861)] to 1.01 [Toxolasma parvum (Barnes, 1823)], whilst the same parameter in Unionini tribe was 0.323-0.412 (Ostrovsky et al., 1993). It should be noted that usually larger values are obtained for longevous mussel species (Hochwald, 2001). For example, Aldrige (1999) reported $K=0.075$ for a long-lived $U$. tumidus population in a Fenland waterway. In contrast, $K$ value for the Oder estuary populations of this species in our study was 0.199 (EMS) and 0.243 (MS). These values fall within the range reported in the literature for $U$. tumidus populations in other European waters (Table 6).

Differences in the mussel growth in various waterbodies may result from the amount of nutrients and primary productivity (Strayer, 2014), which leads to higher amounts and availability of food for these mussels (Riccardi et al., 2016). Hinch et al. (1989) report that calcium and bicarbonate levels are important for the production of mussel shells, and their decline results in a decreased growth of the mussel size and thickness. These factors, as well as an increased water temperature (Lundquist et al., 2019) and other consequences of climate changes across the world may be the factors affecting the mussel growth in the long run. However, $K$ values for the MS group compared with the EMS group did not reveal a significant difference. This indicates that the difference in the longitudinal growth rate of $U$. tumidus shells in the Szczecin Lagoon waters is very small (Fig. 6).

Haag \& Rypel (2011), analysing data from 57 species and 146 populations of mussels, found a 
Table 6 Values of the von Bartalanffy equation parameters for the various Unio tumidus populations in European waters

\begin{tabular}{|c|c|c|c|c|c|c|}
\hline \multicolumn{2}{|c|}{ Waterbody (country) } & $\begin{array}{l}\text { Growth } \\
\text { constant }\end{array}$ & $\begin{array}{l}\text { Asymptotic length } \\
\left(L_{\infty}\right),[\mathrm{mm}]\end{array}$ & $\begin{array}{l}\text { Maximum length } \\
(\operatorname{lmax}),[\mathrm{mm}]\end{array}$ & $\begin{array}{l}\text { Maximum } \\
\text { age (years) }\end{array}$ & Author \\
\hline \multicolumn{2}{|c|}{ Wicken Lode (England) } & 0.075 & 150.7 & 120 & 21 & Aldrige (1999) \\
\hline \multicolumn{2}{|c|}{ Lake Lembolovskoe (Russia) } & 0.25 & 75.84 & - & - & Rizhinashvili (2008) \\
\hline \multicolumn{2}{|c|}{ Lake Krasnoe (Russia) } & 0.09 & 100.30 & - & - & \\
\hline \multicolumn{2}{|c|}{ Gulf of Finland (Russia) } & 0.19 & 79.11 & - & - & \\
\hline \multicolumn{2}{|c|}{ Lake SestroretskRazliv (Russia) } & 0.08 & 124.30 & - & - & \\
\hline \multicolumn{2}{|c|}{ Oredezk river (Russia) } & 0.30 & 86.99 & - & - & \\
\hline \multicolumn{2}{|c|}{ Lake Loyanskoe (Russia) } & 0.38 & 76.14 & - & - & \\
\hline \multicolumn{2}{|c|}{ Lake Ladoga (Russia) } & 0.27 & 87.11 & - & - & \\
\hline \multicolumn{2}{|c|}{ Svir river (Russia) } & 0.31 & 71.59 & - & - & \\
\hline \multicolumn{2}{|c|}{ Kassel (Germany) } & 0.16 & 136.0 & - & - & Nagel 1987 \\
\hline \multicolumn{2}{|c|}{ Crapina-Jijila, Danube (Romania) } & 0.15 & 103.1 & 88.2 & - & Tudorancea (1972) \\
\hline \multicolumn{2}{|c|}{ Thames river (England) } & 0.28 & 88.0 & 85.2 & - & Negus (1966) \\
\hline \multirow[t]{2}{*}{ Oder estuary } & EMS & 0.199 & 93.1 & 83.6 & 12 & Own data \\
\hline & MS & 0.243 & 83.2 & 75.3 & 10 & \\
\hline
\end{tabular}

significant positive correlation between the growth rate $K$ and the longevity of the species. Amongst mussels, long-lived species mainly belong to the Margaritiferidae family (28-190 years), whilst shortlived species of a life span under 14 years belong to Anodontini (Haag \& Rypel, 2011) and Unionini (Abraszewska-Kowalczyk, 2002). For example, Lewandowski \& Kołodziejczyk (2014), whilst analysing the age structure of $U$. tumidus in the Pilica river (Poland), identified individuals aged 1-9 years, amongst which 2-year-old mussels prevailed in the Sulejowski reservoir, 4-5-year-old ones prevailed in the central Pilica river, whilst 1-4-year-old ones prevailed in the lower course of the Pilica. A much narrower age range (1-6 years) for the $U$. tumidus population of Lake Mikołajki was reported by Lewandowski \& Kołodziejczyk (2014). Our study of mussels collected from archaeological excavations from the early Middle Ages and those currently inhabiting the Oder estuary demonstrated the presence of individuals aged 3-9 and 3-10 years, respectively, with a clear prevalence of individuals aged 5 and 6 in both groups. The maximum age, as defined using the formula by Ziuganov et al. (1994), which these groups of mussels could reach was 10 years with $L_{\infty}$ of $83.2 \mathrm{~mm}$ for the MS group, and 12 years with $L_{\infty}$ of $93.2 \mathrm{~mm}$ for the EMS group. These values are much lower than those reported by Aldrige (1999) for the
Fenland Waterway population (21 years), but large variations in the longevity of this species are known in the literature even between populations inhabiting waterbodies located at the same latitude. For example, Annie et al. (2013) in a population of this species from the Gullspång river recorded age groups of 4-20 years, with a clear prevalence of individuals aged 6 and 7 years. In turn, for Lake Kolungen these authors report an age range of 1-13 years, with the largest share of individuals aged 9-10 years. Differences in the age structure in various waterbodies result from mussel mortality rate at particular stages of development, which depends on the environmental conditions, predation and availability of natural habitats. As revealed in the studies of Strayer \& Malcom (2012), high mussel mortality in the aqueous environment is caused by ammonia. Even at low concentrations, unionised ammonia is toxic for freshwater unionid mussels (Newton, 2003). Of importance are also changes in the natural flow of waters, which affect not only the habitats, but also the aquatic organisms (Randklev et al., 2015).

It should be noted that both groups in the Szczecin Lagoon were found to have an age distribution typical of stable populations of that species (AbraszewskaKowalczyk, 2002; Lewandowski \& Kołodziejczyk, 2014). The above may indicate that in both periods the population of the species was not threatened, despite 
clear changes in the environmental conditions, also between the sampling periods (Borówka et al., 2002; Wolnomiejski \& Witek, 2013). Currently, the Oder estuary together with the Szczecin Lagoon are a relatively strongly eutrophicated basin, with a high phosphorus and nitrogen content (Behrendt et al., 2008; Radziejewska \& Schernewski, 2008; Friedland et al., 2019) and an oxygen content usually above $8.0 \mathrm{mg} \mathrm{dm}^{-3}$ (WIOŚ, 2018). Moreover, the basin has been undergoing dredging for more than 100 years (Wolnomiejski \& Witek, 2013; Dąbkowski et al., 2017), which currently can lead to the destruction of many benthic species or elimination of their individual age groups (Weber, 2005). As a result of these activities, as well as the inflow of biogenic compounds from the Oder river catchment area, increased concentrations of nitrates, nitrites and phosphates can be observed alongside a periodic local decrease in the oxygen concentration in water (below $6.2 \mathrm{mg} \mathrm{O}$ $\mathrm{dm}^{-3}$ ) (WIOŚ, 2018), which according to Weber (2005) can reduce the period of $U$. tumidus active functioning to $83 \%$. Nevertheless, it appears that these changes did not adversely affect the longitudinal growth of shells of $U$. tumidus population currently present in the Oder estuary. The above may be due to long-term changes in the environmental conditions and better adaptation of these organisms like mussels in river Ryck (Weber, 2005). Nevertheless, differences in longevity were observed between the EMS and MS groups in the examined waterbody. Shortening of the life span of $U$. tumidus in the contemporary individuals may be caused by factors associated with the trophy of the Szczecin Lagoon (Reis \& Araujo, 2016).

Trophic changes in the Szczecin Lagoon waters observed in the recent decades (Wolnomiejski \& Witek, 2013), caused by increased intensity of agricultural production and nutrient migration to surface waters (Burzyńska, 2019), may result in future elimination of numerous species sensitive to increased levels of nitrogen and phosphorus compounds. Such changes in the environmental conditions especially affect mussels (Cope et al., 2008), which are one of the most endangered groups of animals (Lopes-Lima et al., 2017; Böhm et al., 2020) How significant for the aqueous environment the freshwater mussels are is shown by the fact that they highly support water purification by filtering off bacteria from the water column (Othman et al., 2015). The most common factors considered in the assessment of the mussel resources and planning of conservation works include the present state of the population or variability over short periods of time. This may lead to erroneous conclusions regarding the changes in the species abundance, distribution and composition of groupings, and may result in non-effective conservation works (Wolverton \& Lyman, 2012; Dombrosky et al., 2016; Wolverton \& Randklev, 2016). Therefore, zooarchaeological studies should be considered in ecological and conservation science, since understanding the causes of current state of resources requires long-term historical perspective.

\section{Conclusions}

A comparative analysis of the contemporary (MS) and Early Middle Ages (EMS) shells of the Unio tumidus mussles revealed significant differences in the morphometric parameters. Regarding both the whole sample and particular age groups, a higher mean length $(L)$, width $(W)$, height $(H)$ and thickness $(T)$ of EMS vs MS mussels was observed, which considering a similar growth rate $(K)$ in both groups, may result from differential preservation and/or differential archaeological recovery. At the same time, EMS mussels, as compared with MS mussels, were characterised by a higher longevity (12 and 10 years, respectively), higher asymptotic length ( $l \infty 0,93.1$ and $83.2 \mathrm{~mm}$, respectively) and maximum length (Lmax, 83.6 and $75.3 \mathrm{~mm}$, respectively), which also resulted in higher morphometric parameters $(L, W, H$, $T$ ) of shells in this group of mussels.

The present studies have increased our knowledge of the $U$. tumidus and its distribution in the Oder estuary over long periods, but they also reveal the need of further exploratory analyses in the context of environmental and infrastructural changes of the analysed area affecting the distribution and biology of these environmentally valuable aquatic organisms. Moreover, these studies show the role of zooarchaeological studies in the assessment of the state and structure of the mussel (U. tumidus) population and their usefulness in a better understanding of changes taking place in the aqueous environment. However, the assessment of the length and age structure of mussels must also take account of taphonomic processes, because due to shell decomposition and 
crystallization they make it difficult to draw correct conclusions regarding the changes taking place over the years.

Funding This funding was supported by West Pomeranian University in Szczecin [Grant Number 518-08-56-3181-1], Institute of Technology and Life Sciences [Grant Number 14/ 84/2020].

Open Access This article is licensed under a Creative Commons Attribution 4.0 International License, which permits use, sharing, adaptation, distribution and reproduction in any medium or format, as long as you give appropriate credit to the original author(s) and the source, provide a link to the Creative Commons licence, and indicate if changes were made. The images or other third party material in this article are included in the article's Creative Commons licence, unless indicated otherwise in a credit line to the material. If material is not included in the article's Creative Commons licence and your intended use is not permitted by statutory regulation or exceeds the permitted use, you will need to obtain permission directly from the copyright holder. To view a copy of this licence, visit http://creativecommons.org/licenses/by/4.0/.

\section{References}

Abraszewska-Kowalczyk, A., 2002. Małże skójkowate (Bivalvia, Unionidae) dorzecza Pilicy. Folia Malacologica 10: 92-174.

Aldridge, D. C., 1999. The morphology, growth and reproduction of Unionidae (Bivalvia) in a fenland waterway. Journal of Molluscan Studies 65: 47-60.

Aldridge, D. C., T. M. Fayle \& N. Jackson, 2007. Freshwater mussel abundance predicts biodiversity in UK lowland rivers. Aquatic Conservation Marine and Freshwater Ecosystems 17: 554-564.

Annie, J., B. Ann \& R. Mats, 2013. Spatial distribution and age structure of the freshwater unionid mussels Anodonta anatina and Unio tumidus: implications for environmental monitoring. Hydrobiologia 711: 61-70.

Barthelat, F., J. E. Rim \& H. D. Espinosa, 2009. A review on the structure and mechanical properties of mollusk shells. Perspectives on synthetic biomimetic materials. [W:] Applied Scanning Probe Methods XIII. Biomimetics and Industrial Applications. bhushanb., Fuchs H. (red.). Springer: $17-44$.

Behrendt, H., Opitz, D., Kolanek, A., R. Korol \& M. Strońska, 2008. Changes of the nutrient loads of the Odra River during the last century - their causes and consequences. Journal of Water and Land Development 12: 127-144.

Bocard, D., F. Gillet \& P. Legendre, 2018. Numerical ecology with R. Springer: 1-412.

Bogan, A. E. \& K. J. Roe, 2008. Freshwater bivalve (Unioniformes) diversity, systematics, and evolution: status andfuture directions. Journal of the North American Benthological Society 27: 349-369.
Böhm, M., N. I. Dewhurst-Richman, M. Seddon, S. E. H. Ledger, C. Albrecht, D. Allen, A. E. Bogan, J. Cordeiro, K. S. Cummings, A. Cuttelod, G. Darrigran, W. Darwall, Z. Fehér, C. Gibson, D. L. Graf, F. Köhler, M. Lopes-Lima, G. Pastorino, K. E. Perez, K. Smith, D. van Damme, M V. Vinarski, T. von Proschwitz, T. von Rintelen, D. C. Aldridge, N. A. Aravind, P. B. Budha, C. Clavijo, D. Van Tu, O. Gargominy, M. Ghamizi, M. Haase, C. HiltonTaylor, P. D. Johnson. U. Kebapç, J. Lajtner, C. N. Lange, D.A.W. Lepitzki, A. Martinez-Ortí, E.A. Moorkens, E. Neubert, C. M. Pollock, V. Prié, C. Radea, R. Ramirez, M.A. Ramos, S. B. Santos, R. Slapnik, M.O. Son, A.-S. Stensgaard \& B. Collen 2020. The conservation status of the world's freshwater molluscs. Hydrobiologia: 1-24.

Borówka, R., M. Latałowa, A. Osadczuk, J. Święta \& A. Witkowski, 2002. Paleogeography and paleoecology of the Szczecin Lagoon. Greiswalder Geographische Arbeiten 27: $107-113$.

Burzyńska, I., 2019. Monitoring of selected fertilizer nutrients in surface waters and soils of agricultural land in the river valley in Central Poland. Journal of Water and Land Development 43: 41-48.

Carey, C., J. W. Jones, E. M. Hallerman \& R. S. Butler, 2013. Determining Optimum Temperature for Growth and Survival of Laboratory-Propagated Juvenile Freshwater Mussels. North American Journal of Aquaculture 75: 532-542.

Chełkowski, Z., J. Filipiak \& B. Chełkowska, 2001. Studies on ichthyofauna from an archaeological excavation on WolinTown (Site 1, Pit 6). Acta Ichthyologica Et Piscatoria 31: 61-80.

Cohen, Y. \& J. Y. Cohen, 2008. Statistics and Data with R: an applied approach through examples. John Wiley \& Sons.

Cope, G. W., R. B. Bringolf, D. B. Buchwalter, T. J. Newton, C. G. Ingersoll, N. Wang, T. Augspurger, F. J. Dwyer, M. C. Barnhart, R. J. Never \& E. Hammer, 2008. Differential exposure, duration, and sensitivity of unionoidean bivalve life stages to environmental contaminants. Journal of the North American Benthological Society 27: 451-462.

Dąbkowski, S. L., P. Wesołowski, A. Brysiewicz \& M. Humiczewski, 2017. Międzyodrze: an example of diverse economic and nature-related activities in the part of the Lower Odra Valley. Journal of Water and Land Development 34: 117-129.

DiNapoli, R. J., S. M. Fitzpatrick, M. F. Napolitano, C. R. Torben, J. H. Stone \& N. P. Jew, 2021. Marine reservoir corrections for the Caribbean demonstrate high intra-and inter-island variability in local reservoir offsets. Quaternary Geochronology 61: 101-126.

Dombrosky, J., S. Wolverton \& L. Nagaoka, 2016. Archaeological data suggest broader early historic distribution for blue sucker (Cycleptus elongatus, Actinopterygii, Catostomidae) in New Mexico. Hydrobiologia 771: 255-263.

Dzięczkowski, A., 1998. Badania malakologiczne w archeologii, [w:] Nauki przyrodnicze i fotografia lotnicza w archeologii, red. Wydawnictwo Śmigielski, Poznań: 97-110.

Friedland, R., G. Schernewski, U. Gräwe, I. Greipsland, D. Palazzo \& M. Pastuszak, 2019. Managing eutrophication in the Szczecin (Oder) Lagoon - development, present state 
and future perspectives. Frontiers in Marine Science 5: $1-17$.

Fritts, A. K., M. W. Fritts, W. R. Haag, J. A. DeBoer \& A. F. Casper, 2017. Freshwater mussel shells (Unionidae) chronicle changes in a North American river over the past 1000 years. Science of The Total Environment 575: 199-206.

Ganser A. M., T. J. Newton \& R. J. Haro, 2015. Effects of elevated water temperature on physiological responses in adult freshwater mussels. Freshwater Biology 60: 1705-1716.

Ganzei, K., V. Zharikov, N. Pshenichnikova, A. Lebedev, A. Kiselyova \& I. Lebedev, 2020. Spatial landscape differentiation of the coastal geostructure of the Shkota Island, Sea of Japan. Journal of Water and Land Development 46: 60-70.

Grabarkiewicz, J. \& W. Davis, 2008. An introduction to freshwater mussels as biological indicators. Environmental Protection Agency, Office of environmental Information, Washington, DC.

Graf, D. L. \& K. S. Cummings, 2006. Palaeoheterodont diversity (Mollusca: Trigonioida 1 Unionoida): what we know and what we wish we knew about freshwater mussel evolution. Zoological Journal of the Linnean Society 148: 343-394.

Graf, D. L. \& K. S. Cummings, 2021. A 'big data' approach to global freshwater mussel diversity (Bivalvia: Unionoida), with an updated checklist of genera and species. Journal of Molluscan Studies 87: 1-34.

Haag, W. R. \& A. M. Commens-Carson. 2008. Testing the Assumption of Annual Shell Ring Deposition in Freshwater Mussels. Canadian Journal of Fish Aquatic Science 65: 493-508.

Haag, W. R. \& A. L. Rypel, 2011. Growth and longevity in freshwater mussels: evolutionary and conservation implications. Biological Reviews 86: 225-247.

Hinch, S. G., L. J. Kelly \& R. H. Green, 1989. Morphological variation of Elliptio complanata (Bivalvia: Unionidae) in differing sediments of soft-water lakes exposed to acidic deposition. Canadian Journal of Zoology 67: 1895-1899.

Hochwald, S., 2001. Plasticity of life history traits in Unio crassus. In Bauer, G. \& K. Wächtler (eds), Ecology and Evolution of the freshwater mussels Unionoida. Ecological Studies 145. Springer, Heidelberg: 367-379.

Holland H. A., B. R. Schöne, C. Lipowsky \& J. Esper, 2014. Decadal climate variability of the North Sea during the last millennium reconstructed from bivalve shells (Arctica islandica). The Holocene 24: 771-786.

Hu Z., T. W. Cronin \& E. Tziperman, 2018. Suppression of Cold Weather Events over High-Latitude Continents in Warm Climates. Journal of Climate 31: 9625-9640.

Johnsson, A., A. Bertilsson \& R. Mats, 2013. Spatial distribution and age structure of the freshwater unionid mussels $A n$ odonta anatina and Unio tumidus: implications for environmental monitoring. Hydrobiologia. 711: 61-70.

Kurzawska, A., 2015. Badania malakologiczne w archeologii. W: A. Hyrchała i B. Bartecki (red.), Wojownik i księżniczka. Archeologia - Medycyna Sądowa - Sztuka, Hrubieszów: 104-109.
Lewandowski, K. \& A. Kołodziejczyk, 2014. Long-term changes in the occurrence of unionid bivalves in a eutrophic lake. Folia Malacologica 22: 301-309.

Lopes-Lima M., R. Sousa, J. Geist, D. C. Aldridge, R. Araujo, J. Bergengren, Y. Bespalaya, E. Bódis, L. Burlakova, D. Van Damme, K. Douda, E. Froufe, D. Georgiev, C. Gumpinger, A. Karatayev, Ü. Kebapçi, I. Killeen, J. Lajtner, B. M. Larsen, R. Lauceri, A. Legakis, S. Lois, S. Lundberg, E. Moorkens, G. Motte, K.-O. Nagel, P. Ondina, A. Outeiro, M. Paunovic, V. Prié, T. von Proschwitz, N. Riccardi, M. Rudzīte, M. Rudzītis, C. Scheder, M. Seddon, H. Şereflişan, V. Simić, S. Sokolova, K. Stoeckl, J. Taskinen, A. Teixeira, F. Thielen, T. Trichkova, S. Varandas, H. Vicentini, K. Zajac, T. Zajac \& S. Zogaris, 2017. Conservation status of freshwater mussels in Europe: state of the art and future challenges. Biological Reviews 92: 572-607.

Lopes-Lima, M., L. E. Burlakova, A. Y. Karatayev, K. Mehler, M. Seddon \& R. Sousa, 2018. Conservation of freshwater bivalves at the global scale: diversity, threats and research needs. Hydrobiologia 810: 1-14.

Lundquist, S. P., T. A. Worthington \&. D. C. Aldridge, 2019. Freshwater mussels as a tool for reconstructing climate history. Ecological Indicators 101: 11-21.

Lyman, R. L., 2017. Paleoenvironmental Reconstruction from Faunal Remains: ecological Basics and Analytical Assumptions. Journal of Archaeological Research 25: 315-371.

Masłowski, J., 1993. Long-term changes in bottom macro-fauna of the Szczecin Lagoon (north-western Poland). Acta Hydrobiologica 35: 344-355.

Miller, E. J., J. J. Tomasic \& M. C. Barnhart, 2014. A Comparison of Freshwater Mussels (Unionidae) from a LateArchaic Archeological Excavation with Recently Sampled Verdigris River, Kansas, Populations. American Midland Naturalist 171: 16-26.

Mitchell, J., 2017. Prehistoric Molluscan Faunas of the Yazoo River, Mississippi, USA. Archaeological Perspectives for Modern Conservation. Environmental Archaeology 23: $1-10$.

Mitchell, J. \& E. Peacock, 2014. A Prehistoric Freshwater Mussel Assemblage from the Big Sunflower River, Sunflower County, Mississippi. Southeastern Naturalist 13: 626-638.

Mitchell, J., E. Peacock \& S. Myatt, 2016. Sampling to Redundancy in an Applied Zooarchaeology: a Case study from a Freshwater Shell Ring in the Mississippi Delta, Southeastern USA. Journal of Archaeological Science: Reports 5: 499-508.

Nagel, K., 1987. Untersuchungen an einer Najadenpopulation (Bivalvia; Unionidae) in einem Baggersee bei Kassel (Nordhessen). Philippia VI 5: 383-395.

Negus, C. L., 1966. A quantitative study of growth and production of unionid mussels in the River Thames at Reading. Journal of Animal Ecology 35: 513-532.

Newton, T. J., 2003. The effects of ammonia on freshwater unionid mussels. Environmental Toxicology and Chemistry 22: 2543-2544.

Ogle, D. H., 2016. Introductory Fisheries Analyses with R. Chapmann \& Hall.

Ostrovsky, I., M. Gophen \& I. Kalikhman, 1993. Distribution, growth, production, and ecological significance of the clam 
Unio terminalis in Lake Kinneret, Israel. Hydrobiologia 271: 49-63.

Othman, F., M. Islam, E. Sharifah, F. Shahrom-Harrison \& A. Hassan, 2015. Biological control of streptococcal infection in Nile tilapia Oreochromis niloticus (Linnaeus, 1758) using filter-feeding bivalve mussel Pilsbryoconcha exilis (Lea, 1838). Journal of Applied Ichthyology 31: 724-728.

Ożgo, M., Z. Bogucki \& M. Nowakowska, 2012. Shells of Unio tumidus (Bivalvia: Unionidae) from an archaeological site and contemporary population inhabiting the same lake. Polish Journal of Ecology 60: 839-844.

Peacock, E., 2000. Assessing bias in shell assemblages. Journal of Field Archaeology 27: 183-196.

Peacock, E. \& S. Mistak, 2008. Freshwater Mussel Remains from the Bilbo Basin Site, Mississippi, U.S.A.: Archaeological Considerations and Resource Management Implications. Archaeofauna 17: 9-20.

Peacock, E., J. Mitchell \& C. Jenkins, 2016. Pre-Columbian Freshwater Mussel Assemblages from the Tallahatchie River in the Lower Mississippi River Alluvial Basin, USA. American Malacological Bulletin 34: 121-132.

Peacock, E., J. Mitchell \& C. A. Buchner, 2017. Applied Zooarchaeology of Freshwater Mussel (Bivalvia: Unionidae) Shell fromGolson (22HU508), a Deasonville-Period Site on the Yazoo River, Mississippi. Environmental Archaeology 23: 152-159.

Peacock, E., J. Mitchell \& B. Kirkland, 2020. Investigating Freshwater Mussel (Unionidae) Shell Diagenesis at an Archaeological Site on the Tombigbee River, Mississippi, Southeastern USA. Journal of Archaeological Science: Reports 31: 102350.

Piechocki, A. \& B. Wawrzyniak-Wydrowska, 2016. Guide to freshwater and marine mollusca of Poland. Bogucki Wydawnictwo Naukowe. Poznań.

Pinheiro, J., D. Bates, S. DebRoy, D. Sarkar \& R Core Team, 2020. nlme: linear and nonlinear mixed effects models. R package version 3.1-148. Retrieved from https://CRAN.Rproject.org/package $=$ nlme

Radziejewska, T. \& G. Schernewski, 2008. The Szczecin (Oder) Lagoon. In Ecology of Baltic Coastal Waters, ed U. Schiewer (Springer, Berlin, Heidelberg): 115-129.

Randklev, C. R., N. Ford, S. Wolverton, J. H. Kennedy, C. R. Robertson, K. Mayes \& D. Ford, 2015. The influence of stream discontinuity and life history strategy on mussel com-munity structure: a case study from the Sabine River, Texas. Hydrobiologia 770: 173-191.

R Core Team 2013. R: A language and environment for statistical computing. Vienna, Austria: R Foundation for Statistical Computing.

Reis, J. \& R. Araujo, 2016. Life history of the freshwater mussel Unio tumidiformis (Bivalvia: Unionidae) in a temporary Mediterranean-type stream. Invertebrate Biology 135: 31-45.

Riccardi, N. E., M. Lopes-Lima, E. Froufe \& C. Mazzoli, 2016. When and how? Freshwater mussel recolonization in Lake Orta. Journal of Limnology 75: 120-130.

Rizhinashvili, A. L., 2008. On the relationships between absolute and allometric shell growth in Unionid mussels (Bivalvia, Unionidae) from European Russia. Inland Water Biology 1: 241-247.
Schöne, B. R. \& J. Fiebig, 2009. Seasonality in the North Sea during the Allerød and Late Medieval Climate Optimum using bivalve sclerochronology. International Journal of Earth Sciences 98: 83-98.

Shahbaba, B., 2012. Biostatistics with R. Springer-Verlag New York.

Strayer, D. L., 2014. Understanding how nutrient cycles and freshwater mussels (Unionoida) affect one another. Hydrobiologia 735: 277-292.

Strayer, D. \& H. Malcom 2012. Causes of recruitment failure in freshwater mussel populations in southeastern New York. Ecological Applications 22: 1780-1790.

Tudorancea, C., 1972. Studies on Unionidac populations from the Crapina-Jijila complex of pools (Danube zone liable to inundation). Hydrobiologia 39: 527-561.

Vaughn, C. C. \& C. C. Hakenkamp, 2001. The functional role of burrowing bivalves in freshwater ecosystems. Freshwater Biology 46: 1431-1446.

Warton, D. I., R. A. Duursma, D. S. Falster \& S. Taskinen, 2012. SMATR 3-an R package for estimation and inference about allometric lines. Methods in Ecology and Evolution 2: $257-259$.

Watters, G.T., 2001. The evolution of the Unionacea in North America, and its implications for the worldwide fauna. In: Bauer G, Wächtler K, editors. Ecology and Evolution of the Freshwater Mussels Unionoida. Springer-Verlag, Berlin: 281-307.

Weber, E., 2005. Population size and structure of three mussel species (Bivalvia: Unionidae) in a northeastern German river with special regard to influences of environmental factors. Hydrobiologia 537: 169-183.

Wetzel RG. 2001. Limnology. Lake and River Ecosystems. Academic Press.

WIOŚ, 2018. Stan środowiska w województwie zachodniopomorskim. Wojewódzki Inspektorat Ochrony Środowiska w Szczecinie: 1-183.

Wolnomiejski, N. \& Z. Witek, 2013. The Szczecin Lagoon Ecosystem: The Biotic Community of the Great Lagoon and its Food Web Model. Versita Ltd, London: 1-294.

Wolverton S. \& R. L. Lyman, 2012. Conservation biology and applied zooarchaeology. The University of Arizona Press: $1-241$.

Wolverton, S. \& C. R. Randklev, 2016. Archaeological Data Indicate a Broader Late Holocene Distribution of the Sandbank Pocketbook (Unionidae: Lampsilis satura Lea 1852) in Texas. American Malacological Bulletin 34: 133-137.

Wolverton, S., C. R. Randklev \& J. H. Kennedy, 2010. A Conceptual Model for Freshwater Mussel (Family: Unionidae) Remains Preservation in Zooarchaeological Assemblages. Journal of Archaeological Science 37: 164-173.

Woodward, G., D. M. Perkins \& L. E. Brown, 2010. Climate change and freshwater ecosystems: impacts across multiple levels of organization. Philosophical Transactions of The Royal Society B Biological Sciences 365: 2093-2106.

Zabilska, M., 2012. Depozyty ze szczątkami mięczaków na stanowiskach kultury łużyckiej z Polski. Charakterystyka i próba określenia ich genezy. Acta Universitatis Nicolai Copernici. Archeologia 32: 253-289.

Ziertitz, A., N. F. Mahadzir, W. N. Chan \& S. McGowan, 2019. Effects of mussels on nutrient cycling and bioseston in two 
contrasting tropical freshwater habitats. Hydrobiologia 835: 179-191.

Ziuganov, V., A. Zotin, L. Nezlin \& V. Tretiakov, 1994. The freshwater pearl mussels and their relationship with salmonid fish. VNIRO Publishing House. Moscow.
Publisher's Note Springer Nature remains neutral with regard to jurisdictional claims in published maps and institutional affiliations. 